\title{
Role of Education Commission in development of Primary Education in Bangladesh
}

\author{
*Dr. Md. Khaleduzzaman \\ Associate Professor Institute of Education and Research (IER) University of Rajshahi, Bangladesh
}

\begin{abstract}
The study mainly explores the historical background of reforming the primary education in Bangladesh. The governments of Bangladesh have taken some initiatives as to the expectation to develop primary education in Bangladesh. In some cases it has been seen that the government is successful to implements the policies of various programs in respect of developing primary education in Bangladesh. Many education Commissions have been composed to develop primary education but no Education Commission could be implemented yet fruitfully. Besides, government have taken some projects for primary education to achieve expected enrollment, reducing dropout, increasing completion rate and attain them at school. Food for Education (FFE), Universal Primary Education Project and Primary Education Stipend Project (PESP) are remarkable. The study has tried to examine the programs of the previous government in respect of developing primary education. The study comprised with secondary data along with the documents of various sources within home and abroad, various research work of scholars. Sometimes it tried to explore data from daily news and government's reports. From the study we have to clear the policy and role of education commission in the development of primary education in Bangladesh.
\end{abstract}

\section{Introduction}

Right education for the beginners can empower human beings to liberate individual mind from the curse of ignorance and darkness. It represents the cornerstone in the development process of any society and the key indicator of the people's progress and prosperity Education is the backbone of sustainable development and primary education is its foundation. Education stimulates and empowers people to participate in their own development. ${ }^{1}$ Education has a very vital role to play in the supply of skilled human resources and an intelligent community needed for economic development and for ensuring a democratic social system. Primary education is the base of the system of formal education and as such it is the most significant part of the educational life of a student. It is at this level that attitudes have to be formed, interests and aptitudes developed, and a sound foundation laid for secondary and higher education. Universal Primary Education (UPE), therefore, has been considered a well accepted principle not only in developed countries but also in developing countries like Bangladesh. Article 17 of the constitution of the People's Republic of Bangladesh gives a direction of introducing uniform, mass oriented and universal system of education and extending free and compulsory primary education to all children. Primary education must be made universal because of the direct contribution it makes to national development and also because it is an indispensable step toward achieving the complete literacy of our population. ${ }^{2}$ Education commission plays a great role in development in primary education in Bangladesh.

\section{Primary Education in Bangladesh}

Primary school education is most often referred to as elementary school or grade school and is usually composed of grades one through five. The main purpose of primary education is to give children a strong foundation in the basics of a general curriculum, with emphasis on reading and math. There is the near consensus among the educationists that the primary education is after nursery or preprimary education and before secondary education. It is for children from 5+ to 11 years of age from class's IV. ${ }^{3}$ These schools are known as primary schools.

\section{Aims and Objectives of Primary Level Curriculum in Bangladesh}

There are 22 objectives of primary level curriculum. The objectives of primary level curriculum do mention gender issues directly. Most of the aims indicated gender balance indirectly. They are given below

1. To create confidence and belief on almighty Allah on every learners so that they can build up the same belief and confidence and also be inspired the same in their thinking and practical activities and help them to develop their spiritual, moral, social and human evaluations. 
2. To help children to gain their principle and characters by the guideline of their individual religion.

3. To create awareness in the children, love for all, respect, harmony, compassion, and cooperation and influence them to attract and develop for peaceful environment for all nation-religion-classes, menwomen.

4. To create eagerness among children for human rights, mutual understanding, cooperation, international brotherhood, internationalism feeling and world peace and culture.

5. To build learner's attention for labor work, to create good attitude to respect working class people and also to create awareness for better life through financially benefited labor workers.

6. To build consciousness in children, about own and other's rights, duties and responsibilities learning from direct participation in the family, social and schooling activities.

7. Helping children to practice for extreme tolerances and for democratic rule and regulations.

8. Inspiring the children on freedom fighters consciousness to build their mind patriotic and also to open the door of nationalism from them, creation good mind for sacrifice and inspiring them for country building activities.

9. To acquire knowledge for national history, heritage and culture and helping children to internal lookout and also creating awareness to make respect for the said matters.

10. To help children for building their good health through physical exercises and games and also to help them to get the habit for hygienic living.

11. In all aspects and activities of life ensuring them to learn basic skill through Bengali medium.

12. To give proper teaching to gain mathematical impression and knowledge, logical thinking and growing ability to resolve their own problems.

13. As foreign language, elementary knowledge must be taken care of and helping them on use of this language.

14. Learning-skill and knowledge, on this subject creation curiousness and this way grow interest in them for education as lifetime achievement.

15. For development of lifestyle gives them knowledge of science and technology, teaching them to resolve problems scientifically and make them habit of it helps them to create scientific lookout.

16. To help acquire knowledge on different sources of information as medias, computer or projector presentation.

17. To make awareness and help understand children about environment and to teach them how to take preventive measure for environment actively by their direct participation and to inspire them for development and preservation of it.

\section{History of the Development of Primary Education: British Period up to 1947)}

Primary Education as it is understood today in Bangladesh was first recommended in a despatch known as 'Wood's Education Despatch' in 1845. ${ }^{4}$ The recommendation was for the establishment of graded school system from universities/colleges to primary schools at the bottom. The Despatch also recommended education for the masses through aided indigenous elementary schools. Education for the masses was somewhat a new concept. The recommendation remained mostly unimplemented by the newly established Department of Public Instruction because of resource constraints. India became a British colony in 1861. Between 1861 and 1871 local taxes were imposed to meet the cost of primary education except in Bengal where the peculiar land revenue system known as Permanent Settlement presented an obstacle. But a large government grant coupled with opening of a number of indigenous schools at local initiative, but mostly aided, helped the province to achieve considerable expansion of primary education. A Commission was appointed by the then Viceroy of India, Lord Rippon in 1882 Known as India Education Commission to review the development of education in India since the 'Wood's Despatch' and to suggest measures for carrying out the policy decisions made there in with particular reference to Primary Education. ${ }^{5}$ The Commission recommended that the control of primary education be made over to the local bodies (District and Municipal Boards) because of limited funds at the disposal of the government for management of primary schools; the local bodies would raise funds locally and through subsidy from the government as well as school fees to be paid by the pupils. The Commission declared that primary education would have an almost exclusive claim on local funds and a large claim on provincial revenues. Some of the achievements in the field of primary education during 1834- 1902 period were construction of school buildings, improvement of training and qualification of primary teachers, admission of girls and pupils of low caste, and use of printed books. The method of teaching was improved by using objective lessons, more humane treatment to the child in the class room and use of teaching aids. Lord Curzon who took over as Viceroy of India in 1898 proved to be a great educational reformer. He followed a policy of giving larger grants to primary education both non-recurring and recurring. In the decade 1917-27' some of the provinces in India including Bengal passed Compulsory Education Act to be implemented in selected rural and 
urban areas for children of both sexes, The local self-government institutions were made responsible for enforcing the compulsion. In 1935 Government of India Act was passed introducing provincial auto" nomy and all matters regarding education excepting a few central subjects were transferred to the provinces. Immediately, compulsory primary education issue started attracting attention of the provinces. Another trend of this period was to withdraw powers given to local bodies over primary education. In 1944 a comprehensive rational plan of education known as Sergeant Report was prepared. It provided for pre-primary education for children between 3-6 years, and universal compulsory and free primary education for all children between $6-14$ years divided into Junior Basic (6-11 years) and Senior Basie (11-14 years) stages. This was to be achieved in 40 years time.

\section{Pakistan Period (1947-71):}

On the partition of India the geographical area now forming Bangladesh became a province of Pakistan. The new country adopted the same objective of universal, free and compulsory education for all children between 6-11 years extending it to cover all children upto 14 years its first national conference on education held in November, 1948. Universal free primary education was a major goal of national planning in the First Five Year Plan (1955-'60). The Plan hoped that free and compulsory primary education would be possible in about 20 years, During the First Five Year Plan no noticeable progress was made in primary education excepting some improvement in teacher's salaries. The enrolment increased by less than $50 \%$ form what was planned. On the eve of Second Five Year Plan (1960 - 65), a National Education Commission was set up in 1959. The Commission recommended that 5-year primary school course should be made universal and compulsory within next 10 -years and compulsory education of 8 -years schooling should be introduced and implemented within next 15 years. ${ }^{6}$ It recognized the problem of dropping-out from schools and advocated a system of promoting children by age at the end of the year rather than by results of the tests. The Third Five Year Plan (1965-70) aimed at increasing enrolment from $45 \%$ to $70 \%$ of the primary school age-group children in 1970 mainly by increasing girls' enrolment. Primary Education did not enjoy the priority it deserved in none of the three Five Year Plans executed during the Pakistan period (1947-71) although there was no dearth of rhetoric championing its cause. ${ }^{7}$ The share of primary education out of the total allocation in the education sector was around $22 \%$ and actual utilization of allocated fund was much less.

\section{The Primary School (Taking Over) Act, 1974}

After the independence in 1971, the constitution of the newly born country recognized the need for basic education for all and measures to implement universal primary education were taken from the beginning. As a first step towards achieving the constitutional directive of universal primary education, the government issued a 'Decree of Nationalization' of all 36,165 primary schools in the country in 1973. Thus the government took the whole responsibility of financing, managing and supervising all primary schools in the country. The Act of 1974 provided free primary education all over the country. ${ }^{8}$ The teachers of the schools became the government servants. However up until recent times, enrollment, as well as government spending on the education sector, has remained very low; little progress was seen in the primary education sector throughout the $80 \mathrm{~s}$.

\section{The Primary Education Act, 1981}

The Act made provision for the establishment of Local Education Authorities (LEAs) at the subdivisions (now abolished). Extensive powers were to be delegated to these LEAs and their executive committees headed by bureaucrats and primary education officers. The Act reestablished school based management through the formation of school management committee. The organizational structure and period of LEAs was as under:
1. 5 ex -officio members
2. nominated members
3. women members
4. elected Gram Prodhans
5. ex-officio chairperson and secretary 6 . elected vice chairman, and
6. a four year term.

As stated earlier a managing committee consists of 11 members was established for every school under the Bengal Rural Primary Act of 1930. The structure of the School Management Committee was as under:

1. Gram Prodhan of Swanirvar Gram Sarkar

2. Village Chief of self- reliant village government- ex officio member

3. the school head- secretary

4. two nominated educationist-members

5. one nominated benefactor-member 
6. one elected teacher representative- member and

7. four elected guardian representatives-members

The functions of the School Management Committee were as follows:

1. managing the affairs of the school

2. supervising the school

3. executing the development plans of the state and the local government, and

4. ensuring regular attendance of the teachers and students. However, the Primary Education Act of 1981 with the innovative features of the LEA decentralization was not implemented.Decentralization of Powers and Functions Relating to Management of Primary Education (Executive Order of the 15 August 1983). The Primary Education Act, 1981 was obsolete by the executive order of the Ministry of Education on 15 August 1983, which put the responsibility of the management of primary schools on the Upazila Parishad. ${ }^{9}$ The Upazila Parishad was created from the existing Thana Parishad. Accordingly, primary education along with other development activities was transferred to the upazila. The powers, of the Upazila Parishad with regards to primary education are as under:

1. Appointment, promotion and transfer of teachers

2. Supervision of upazila schools

3. Preparation of annual school and development budgets

4. Distribution of textbooks and teaching aids

5. Registration of private primary schools.

Each upazila must have an Upazila Primary Education Committee (UPEC) consisting of: ${ }^{\mathrm{i}}$

1. Five ex-officio members

2. One nominated educationist member

3. Two nominate Secondary School Heads (one male and one female) and

4. upazila education officer, member secretary

The functions of the committee involved assisting the Upazila Parishad with regard to the management of primary education. In addition to the above every school must have a managing committee consisting of one ward member of the union Parishad, the school head, one educationist, one donor member, one women member, and two teacher representatives with an elected chairman from among its members for a term of three years.

\section{The Primary Education (Compulsory) Act 1990}

It is only in recent years that the nation has come to acknowledge of the magnitude of the problem. In light of our constitutional directive the Primary Education (Compulsory) Act 1990 (Act 27 of 1990) was enacted in February 1990. ${ }^{10}$ The Ministry of Education made detailed administrative arrangements for different levels to implement, coordinate and monitor the compulsory primary education (CPE) program. The whole country was brought under the CEP program in 1993. The challenge is a huge one mainly because of the size of primary school-age population and vast amount of resources required.

The Act 1990.

- $\quad$ provided ward, union, upazila and district CPE committees for effective implementation and coordination of CPE programs in their geographical areas;

- Involved ministers, state ministers, deputy ministers and parliament members as advisers in the district and upazila level committees respectively.

- ensured women representation and participation in all committees; Suggested Deputy Commissioners (DC) and Upazila Nirbahi Officers (UNO) as CPE committees' chairpersons at districts and upazilas;

- $\quad$ ensured membership of local educationists and municipal bodies in the CPE committees;

- $\quad$ provided education officer to act as secretaries of all CPE committees;

- $\quad$ standardized frequency of meeting for all CPE committees;

- $\quad$ provided supervision, reporting, and monitoring mechanisms for CPE programs;

- $\quad$ describes the functions of all CPE committees;

- $\quad$ established procedures and norms for the enforcement of compulsory primary education and

- Provided community participation and social mobilization role to school management committees and parent teacher associations.

The primary education programs dramatically improved in the latter half of 1990s. A large part of this achievement was a direct result of the 1990 World Conference on Education for All (WCEFA), which encouraged all participating nations to expand their vision to meet goals in the education sector, especially the goal of making primary education universal. Following this conference, donors in Bangladesh invested in 
the education sector much more heavily and NGOs increased their involvement in assisting the Bangladeshi government in meeting its primary education goals. The Government of Bangladesh itself took many initiatives in the years following the WCEFA, including: the 1990 Compulsory Primary Education Act, which made the five-year primary education program free in all government schools and declared education for girls in rural areas free through grade eight; the establishment of the ministry for Primary and Mass Education in 1992, which set as its objective the universalizing primary education as well as the elimination of the gender- and poverty-gaps; demand-side interventions such as the Female Stipend program, the Food for Education (FFE) program; and most recently the Primary Education Development Program (PEDP II), a six-year program beginning in the year 2000 which aims to increase access, quality and efficiency across the board in the primary education sector. ${ }^{11}$ These measures have resulted in impressive gains in the achievement of Bangladesh's primary education goals. However, Bangladesh still faces obstacles towards the long-term success of its education system. For example:

\section{The National Education Policy 2000}

The National Education Policy 2000 states that primary education should be universal, compulsory, free and of same standard for everybody. Quality primary education for all is a must for the development of the country and as such proper steps should be taken to make the standard of primary education appropriate for the times. The policy states the objectives of primary education as under ${ }^{12}$

1. To ensure standard practical literacy for a child and make him eager and capable of receiving higher level education.

2. To enable the child fulfill the basic needs of education by acquiring essential knowledge, skill, attitude, values and social consciousness for leading life properly and prepare him for the next stage of education.

3. To inspire the child develop patriotism and encourage him to nation building activities by arousing consciousness about the Liberation War.

4. To enable the child acquire competence for solving the problems of life by developing creative capability and attraction towards income generating physical labor.

5. To help the child develop moral and spiritual qualities like righteousness, sense of responsibility, discipline, good manners, human rights, tendency to lead a simple life, curiosity, amicability, friendliness, diligence etc. and to create aptitude in him for science and culture

\section{Reforms Suggested in Different Education Commission Reports}

As stated earlier that education is the key to all sorts of development. Education provides an individual the required skills to lead a life with honor and dignity. "It fosters the growth of their personality, transmits the culture of the nation to its new generation and socializes the children to be law abiding citizens of the country. So it can safely say that history of education of a country is really the history of development of a country". ${ }^{13}$ Primary educations is the foundation of formal education in Bangladesh. Primary education has a long history, which goes back to the period of British rule in

India. In 1835, Rev. Adam had suggested one primary school compulsorily for every village. In 1852, Capt Wingate, the Revenue Survey Commission of Bombay suggested taxation for the education of the children of the peasant population.

\section{Wood's Education Dispatch of 1854}

The celebrated Wood's Education Dispatch of 1854, resulting from an enquiry about education in India by Select Committee of British House of Commons, provided the legal foundation for modern public education in Bengal. The Dispatch of 1854 also recognized the Government's duty to primary education. ${ }^{14}$ Lord Stanly in the Dispatch of 1859 recommended that government should take responsibility for primary education. The dispatch of 1859 also suggested that the govt. should levy a local tax, if necessary, for the purpose of financing primary schools. But the real beginning of modern primary education in Bengal was made in 1982. Thereafter, the National Education Movement forced the nation to turn its attention to the need for mass education.

\section{Indian Education Commission, 1882}

Lord Ripon appointed the first Indian Education Commission on February 3, 1982 with William Hunter as its Chairman. This commission is popularly known as Hunter Commission. Dadabhai Naorji, the great old man of India, in his evidence before this Commission suggested for universal elementary education in the then British India. The Commission put forward a proposal for universal primary education and recommended that the District and Municipal Board to be entrusted with the 
responsibility of managing primary education through a system of local taxation. On March 19, 1910, Sir Gopal Krishna Gokhale made valiant but unsuccessful efforts in the Central Legislature (1910-12) to induce the Central Government to accept the responsibility to provide universal primary education of four years to all children, and that a mixed Commission of the officials and non-officials should be appointed at an early date to frame a definite proposal. ${ }^{15}$ This Bill was supported by eminent leaders including Quaid-i-Azam Mohammad Ali Jinnah who, strongly advocating the principle of compulsion, said.

\section{Central Advisory Board of Education Report 1944}

In 1944 an important document with regard to the development of education was published. It was drawn up by the Central Advisory Board of Education which had about forty members, official and nonofficial, and as its chairman was Sir John Sargent, it is generally known as the Sargent Report. It proposed the establishment of nursery schools on a voluntary basis for children under six, while from six to fourteen years of age education should be free and compulsory for both boys and girls in a phased program. spread over 40 years (1944-1984). ${ }^{16}$ The report of the Central Advisory Board of Education for the fist time recognized and accepted the need for a national system of education for both boys and girls which will provide the minimum preparation for citizenship. In spite of all these efforts, however, the actual progress of elementary education was very limited and it was carried out through individual initiative of the enlightened segment of the society. Before the partition of the Indo-Pakistan Subcontinent there had been a network of indigenous elementary schools such as Patshalahs, Maktobs, Tolls, etc. Most of the villages had an elementary school, although in many cases formal school buildings did not exist. Even most of the cases only one teacher was engaged in teaching the children of one or a few families. The course curricula were very simple and the period of education was two to four years.

\section{Educational Reforms Commission, 1957}

The Commission was headed by Ataur Rahman Khan, the then Chief Minister of East Pakistan, and consisting of eminent educationists and educational administrators. ${ }^{17}$ The Commission is popularly known as Atuar Rahman Commission 1957. The main objective of the Commission was to advise the government on the organization, restructuring and management of education system in East Pakistan. Chapter III of the report covers the recommendations for primary education. The Commission also suggested for universal, free, and compulsory primary education in East Pakistan.

\section{National Education Commission 1958}

It was appointed at the end of December 1958 and submitted its report in August 1959. Mr S. M. Sharif was the Chairman of the Commission and as such it is popularly known as Sharif Commission 1958. ${ }^{18}$ The Commission recommended for implementing five year compulsory education by 1970 . For this purpose, program was undertaken to project the number of primary school age children and the requirement of teachers. Programs were also drawn up for the training of teachers, production of standard textbooks, and for the building and equipment of schools. This was followed by estimates of the costs involved and methods of financing by the Government and the local communications. Attention was also given to the means which would ensure the retention of a maximum proportion of students enrolled for the full five years. The recommendations of the Commission on primary education are appended below:

- The duration of compulsory elementary education should be eight years and this should be achieved in fifteen years. While five years' compulsory schooling should be achieved within ten years.

- Land, buildings, furniture, etc. required for compulsory primary education are to be provided by each community.

- Current expenses are to be the responsibility of the provincial governments (especially education tax and general revenues).

- The courses taught to the child aged five plus to ten plus should naturally be adapted to the mental abilities of this age group, and be so designed as to develop fundamental skills to a level sufficient for a child to cope with most normal situations in every-day life. The curriculum should, in addition, include courses in simple science and social studies which will give the child an introductory knowledge of the world around him.

Recommendations of National Education Advisory Council for Interim Education Policy 1979 National Education Advisory Council was formed by late president Zaiur Rahaman in 1978 to give recommendations for formulating Interim Education Policy. The committee headed by Kazi Zafor Ahmed till October 11, 1978 and thereafter by Abdul Baten. ${ }^{19}$ It is popularly known as Kazi Zafor Education Commission 1979. The committee was composed with 42 members and headed by Kazi Zafor 
Ahmed, the then Education Minister, till October 11, 1978 and thereafter Abdul Baten, the then State Minister for Education. The members were selected from renowned educationists, well known social workers, and high ranking government officials. The committee provided recommendations for interim education policy in February 8, 1979. The main recommendations for primary education provided in chapter two are presented below:

i. The duration of primary education should be five years and this education would be for the child of five or more years (2.2).

ii. Primary education should be universal, compulsory and free. Current system of free primary education up to class five should be made compulsory in 1983. Class one would be made compulsory in 1979, class two in 1980, class three in 1981, and class four in 1982 respectively $(2.3)$

iii. Thirty thousand new primary schools are to be built so that there would be one school for one village. In these schools only one room is to be built for the first year. For each successive year one class room is to be added in each of the school buildings (2.4 a).

iv. Each year 30,000 new teachers should be appointed and in total about 150000 teachers should be recruited by 1983 (2.4 f).

v. The medium of instruction should be Bengali language (2.8).

vi. Union Education Committee should distribute textbooks and study materials to the children of marginal farmers and other poor parents (29).

vii. Service rules for primary teachers are to be formulated and the primary teachers all over the country are to work under the same system (2.11).

viii. There should be separate division under the Ministry of Education to formulate policies, prepare plans, arranging finance, prepare laws, maintain standard of education, coordination, etc.

ix. The head teacher of the primary schools should be held responsible to the school managing committee for day to day administration of the school (2.15)

x. The Union School Committee would decide the school time considering local geographical condition, weather, production season, and economic and social functions (2.16).

\section{Bangladesh National Education Commission Report 1988}

This report is popularly known Mofizuddin Ahmed Education Commission Report because the commission was headed by Mr. Mofizuddin Ahmed. ${ }^{20}$ In the preamble the commission opined that education is main instrument for national development and growth of human feelings and mental attitude and the foundation of that education is primary education (6-11 years age group). ${ }^{21}$ The main recommendations of the commission on primary education are appended below:

- The present 5-year period of primary education must be universal, free and compulsory by 1995 . Gradually, by 2000, 8-year period primary education should be introduced.

- Primary education is foundation of higher and subsequent education and for some students it is the terminal education. The primary education curriculum should be prepared in such a way that the education received by them help them in their present and future life. Bangla, mathematics, introduction to environment, job experience and religious instructions etc. must be included in the syllabus.

- The minimum qualification of primary teachers should be at least a second division Higher Secondary Certificate or equivalent. Teachers should have pre-service and in-service training facility.

- The post of Assistant Head Master in charge of academic supervision in schools is to be created.

- The system of monitoring, inspection, and investigation need to be strengthen.

- The National Primary Academy at Mymensingh should be developed and strengthen so that the academy can make mentionable contribution to the improvement of curriculum and syllabus, preparation of training kids, and in conducting training related research.

- At the primary level, students should be evaluated throughout the year. The school authority after conducting at least three examinations including the annual examination should preserve the cumulative evaluated records. Guardians should regularly be informed of the progress of students.

- The Department of Primary Education and the National Curriculum and Textbook Board should prepare a sampled Question Bank for all classes and subjects of the primary layer.

\section{Shamsul Haque Commission 1997 (National Education Policy Formulation Committee 1997)}

The committee is headed by Professor M Shamsul Haque and as such it is popularly known as Shamsul Haque Commission. The commission 
suggested that

- $\quad$ the period of primary education will be 8 years by 2010 .

- the curriculum at primary and other streams of education to be uniform. Medium of instruction to be Bengla and English language, religion and moral education to be included in the course curriculum from class three.

- the teacher -student ratio to be $1: 35$

- the evaluation in classes one and two to be continuous, whereas from class three there would be interim and final examinations. There should be scholarship examinations at the end of classes five and eight.

- the requisite minimum qualification for lower primary level be SSC with ${ }^{2 \text { nd }}$ division, for upper primary level degree (Pass) with $2^{\text {nd }}$ class and for head teacher it should be degree with $2^{\text {nd }}$ class but he/she should complete C-En-Ed within three years

- the school management committee to be active.

- there should be relation between professional development of teachers and their promotion.

\section{Education Reforms Expert Committee 2002}

The committee was headed by Professor M. A. Bari and as such it is popularly known as Bari Commission. $^{22}$ The main recommendations of the commission on primary educations are appended below:

- Teacher appointment policy at the primary level should be revised immediately to fix up equal qualification for both male and female and the requisite qualification should be SSC and HSC with second division in both the examinations.

- The present system of both written and oral examinations to be continued and marks in written should be 90 and oral 10 only.

- The primary teacher selection committee at the district level should be composed of:

(i) Principal, Government College

(ii) District Primary Education Officer

(iii) Representative of the Deputy Commissioner

(iv) Super, PTI / Head Master of the Govt. High School

(v) District Education Officer

Chairman

Member Sectary

Member

Member

Member

- $\quad$ There should be job description of primary teachers

- There should be continuous examination in classes I and II and there could be two interim examinations from classes' I-V.

- In the school management committee the number of Guardian representatives should be increased to 6 from 3 and there should be 3 female guardian representatives.

- Introduction of ACR at non-govt. schools and Madrasha

\section{National Education Commission -2003}

The Commission was headed by Professor Maniruzzaman Miah and as such the Commission is popularly know as Maniruzzaman Miah Education Commission, 2003. ${ }^{23}$ The main recommendations on primary education are presented below: (NAEM Journal June 2006, p.70-72) Ensure admission of all children of five years old in school and for that reason admission procedure is to be run round the year.

- Ensure that every child shall complete the primary education

- Ensure establishing a primary school for every 1500 people and for that purpose minimum one hundred primary schools should be established per year. Finnish mapping quickly for establishing new primary school.

- Prioritize those areas which are school-less, remote and where the small groups of indigenous people live and the number of schools are not adequate in comparison to population

- Recurrent expenditure for non registered primary school building and teachers salary should be paid from the government budget.

- Academic hours should be 220 for class I, 720 for class II, and 1275 for classes III-V.

- Within 8 to 10 years teacher-student ratio should be reduced to 1:25 from the present ratio of $1: 30$.

- There should be an independent commission for the recruitment of teachers.

\section{Primary Education in Different Five Year Plans}

Since 1947 up to now different five year and two year plans have been prepared and promises have been made in those plans to universalize primary education in the country. But there 
is hardly any thorough assessment of all those plans to find out the achievement of universal primary education in Bangladesh. In following section an evaluation of different five year and two year plans of Bangladesh has been made.

\section{Primary Education in Different Five Year Plans from 1947 to 1971}

The $14^{\text {th }}$ August, 1947, tolled the knell of British control over India and sang merrily the birth of two sovereign states-Indian Dominion and Pakistan, on the eastern hemisphere. ${ }^{24}$ Since 1947 many plans and programmed such as the "Compulsory Primary Education Scheme, 1951, the "First Five Year Plan (195560)". The "Second Five-year Plan (1960-1965)", and the "Third Five Year Plan (1965-1970)", had planned to improve primary education scenario in Pakistan. The First Five-year Plan stated that in East Pakistan existing 26,000 primary schools were sufficient in number, but out of which 6,000 of them were to be improved. During the plan period apart from minor increase in teachers' salary very little was done in East Pakistan. The First Plan proposed the raising of the basic qualifications of teachers mainly those of primary teachers; the development of training institutions and curricula; provision for facilities of inservice training. During the Plan period only one primary training institute was setup. Some qualitative improvements were made in the existing institutions, and entry qualifications for the training institutes were raised, in general, to matriculation standard. The objective of the Second Plan was to raise the enrolment of children in schools in the age group of 6 to 11 years. The percentage was to be augmented to 60 percent by 1965 from the existing figure of 42.3 percent. In the starting of the Second Plan the number of primary school in East Pakistan was 26,330, which was enough but their average standard in terms of buildings and equipments, regular supplies, capable teachers, and academic environment was poor. Out 26,300 schools, 13,300 were to be provided with better buildings and equipment, regular supplies, and more qualified teachers. These attempts were anticipated to augment primary school enrolment in East Pakistan by 1.3 million, raising the percentage of school attending children from 48 percent to 63 percent. Two special problems were to receive attention in the Second Plan period: first, the provision of adequate facilities for the education of girls, and second a revision of the primary school curriculum to bring into the harmony with the needs and abilities of young children. Out of 4.7 million children attending primary schools, only 1.1 million were girls. This was to be done through the provision of admitting more girls to the existing primary schools, and if needed ensuring separate schools for them. 'East Pakistan's share of the allocation for education in the first two plans was 45 and 47 percent respectively, but its actual expenditure was only around 35 percent of the total allocation for the first two plans. In 1956 the average salary of a primary school teacher was Rs.22 (\$4.22) only. By 1963 it had grown to about Rs.60 (\$12) but even this raise was not enough to magnetize very knowledgeable and competent teachers-especially in view of the fact that the initial salary for an untrained teacher, and these were the majority, was only Rs.32.5 (\$6.80), with annual increase of Rs. 1 (\$0.21) per month. ${ }^{\text {ii }}$ The great majority of East Pakistani children got no further education than class L For every 100 who entered into that class only 40 survived to class II and only about 15 to class V. This of course means that only a small proportion received the four or five years of schooling considered essential to implant lasting literacy. The percentage of literacy increased from 78.90 percent to 82.39 percent during 1951-61 though primary school enrolment increased to 3.33 million (135.97 percent) in 1960-61 from 2.45 million in 1950-51. A survey carried out in 1960 showed that there were 26,024 primary schools in East Pakistan, a provision of one school for every 3.4 square miles or for every 2,000 of the population. Out of these, nearly half were temporary and fragile structures of either thatched shed or gol leaf shed construction. Slightly more were of mixed construction, part permanent (pucca) and part impermanent (Katcha): only 882 were entirely pucca. In the rural area only 54 percent of the children were provided with seating arrangements. A majority of the schools had playgrounds, and fewer than half provision for drinking water- this is an area where water-borne disease takes a severe toll of health and life. The number of children enrolled in these schools was 3,059,713, out of which about one-third were girls. These children were taught by 78,569 teachers, giving a student teacher ratio of $39: 1$. Out of theses teachers, only 24 percent had educational qualification and professional training; 39 percent had the training but not the educational background; 20 percent had the educational background but not the training; the reminder had neither educational background nor training. As such the quality of education offered in most of these schools was low and not up to the mark.

The Primary education scenario in Bangladesh during 1950 to 1972 has been presented below to highlight the failure of implementing universal primary education.

\section{Primary Education in Different Five Year Plans since 1972}

Different Five Year and Two Year Plans of Bangladesh placed high priority to the development of primary education based on the constitutional directive of ensuring basic education for all children 
free of cost. The review of those Plans relating to primary education has been presented below:

\section{The First Five Year Plan 1973-1978 and Two Year Plan 1978-1980}

It was expected in the First Five Year Plan that all children must be assured of basic formal education at least of the primary level and higher education should be selective only for the meritorious and capable young men and women. It was also expected that the primary schools should operate for 220 days in a year, and should be used for two shifts with teachers teaching in both the shifts. Each teacher would teach a group of 50 pupils, each shift receiving an average of three and a half hours of instruction per day. ${ }^{\text {iii }}$ In the Plan eight major objectives relating to primary education were specified, those are as under.

(i) Total enrolment was to be increased to 8.6 million from a base of 6 million.

(ii) The percentage of primary age-group children attending schools was to be increased from 58 percent to 73 percent in 1978.

(iii) Ninety percent of the primary age group boys would be given access to primary education during the Plan as against 76 percent in 1973.

(iv) Girls' participation would be accelerated and their enrolment was to be increased to 55 percent during the Plan period as against 40 percent in 1973.

(v) The course curriculum at the primary level would be thoroughly revised to make it more relevant to real life situation.

(vi) Textbooks and instructional materials were to be supplied to all school going children free of cost or at subsidized rate.

(vii) Textbooks and instructional materials were to be supplied to all school going children free of cost or at subsidized rate.

(viii) Drop-out rate was to be reduced to 52 percent from 62 percent by undertaking complementary and non-formal measures such as well-designed educational program through radio and television. Innovative measures such as provision for feeder schools, child feeding, female teachers, games and recreational services and coordination of holiday with harvesting seasons, were to be introduced to decrease drop-out between class I and II, where the problem was more severe.

(ix) Educated housewives were to be encouraged to teach in primary school.

The projected enrolment target of boys and girls and their ratio are shown in the following table.

Table 2: Projected Enrolment Target in Primary Schools (In million)

The objective of increasing the enrolment of primary age group boys and girls could not be achieved by the end of the First Plan period or even by at the end of Two Year Plan. The achievement of enrolment in primary schools was 70.0 million in 1980 as against 68 million in 1978 and 60 million in 1973. Thus enrolment increased to 103 percent in 1980 over 1978 and 117 percent over 1973. The enrolment of girls during 1973-80 was increased from 0.20 million to 0.224 million (112 percent). The number of primary school teachers increased from $1,24,146$ in 1973 to $1,59,000$ (128.2 percent) in $1980 .{ }^{25}$ Although the drop-out rate was proposed to be reduced available indications suggest that it continues to be the high. The increase in enrolment over the period was very low. One of the main reasons was the large scale poverty of the people due to grave famine of 1974. The poor parents could not send their children to schools and even they had to withdraw their children from schools, those who were already enrolled. These children became a part of the child labor force of the country. Another important reason was the increase of educational inputs like textbooks, pens, pencils, khata, drawing books, eraser, etc. The most important was the lack of commitment of concerned authorities of the government to achieve the plan target. The government also could not achieve the target of providing free or subsidized books and writing materials to the children. Even by the end of Two Year Plan it was not possible to distribute books free of cost to fifty percent of the class I students. As stated earlier a curriculum committee was set up for revising the course curricula in order to meet the needs and aspirations of the society and to reflect the rich heritage and culture of the country. But the curriculum was revised without any major change and as such the curriculum could not reflect the expectations of people of the country. In the year 1978 new textbooks were introduced for class I to V, but the textbooks remain the same in style and contents. Only change was omitting references of Pakistan period. However, the most remarkable step was the nationalization of primary schools. Total expenditure for education and religious affairs during the First Five Year Plan and Two Year Plan period( 1973-80) together was Tk.2588.5 million ( 57 percent achievement) as against the allocation of Tk.4540.1 million. This poor achievement was due to shortage 
of resources. During the same period, a total of 7730 war damaged schools $(96.6$ percent achievement) were reconstructed under UNICEF assistance programmed as against the target of 8,000 schools, and development work of 10,033 schools (50.2 percent achievement) were completed as against the target of 20,000 schools. Feeder school programmed was taken up which showed some success in increasing enrolment and reducing dropout, but the actual statistics is not known. Despite the criticisms, the First Five Year Plan was the base work and put the foundation for the successive plans.

\section{The Second Five Year Plan 1980-1985}

The Plan gave importance to primary education and allocated 41 percent of the total allocation of fund for education. One of the objectives of the Plan was to eliminate illiteracy and make a significant advancement towards a widespread development of human assets. The Plan quotes positively from studies viewing that literacy equates positively with superiority of work, fertility levels, and economic growth. ${ }^{\text {iv }}$ The Plan states that the objectives of attaining better quality of life for the mass can be realized better if the population is literate. The ability to read and write is an important asset of man in modem life. It helps in the efficient use of modern inputs in farming, transaction in business with banks, cooperatives or land administration, use of family planning devices and finally, and above all, in the use of democratic rights of a citizen. Universal primary education is indeed a precondition of modernization. Removing illiteracy from the country is, therefore, considered as a strategy for social and economic development of the masses. Since resources are limited, there cannot be simultaneous increase of investment of public funds at all levels of education. It is necessary to economize in all other sectors of education through confining the higher education only to the meritorious, increasing the efficiency of existing institutions through realization, making the private sector pay more for higher education, etc. Thus the expansion of primary and mid-level technical education at public cost, along with increasing dependence on the private sector for education, is recommended as a strategy for the Plan.

The Plan accorded top most priority to the introduction of universal primary education by 1985 and with this end in view, about 47 percent of the total allocation to the education sector was earmarked for this programmed. Of the total allocation of Tk.7070 million, Tk.3317 million (46.9 percent of the sectoral allocation) was allocated for the development of primary education. Actual expenditure on Universal Primary Education was, however, Tk.2107 million or 41.4 percent of the estimated expenditure on education. This Plan gave pinnacle importance to the beginning of Universal Primary Education (UPE) free of charges, but the success puts a big question mark. By the end of the Plan period (19\$5), total enrolment stood at 8.92 million (68.6 percent achievement) as against an ambitious target of 13 million. Provision was made to provide with free uniform to the girl students in order to increase the women education, but due to management problems the program was discarded. More reveling is that only 11,274 class-rooms were constructed (48.3 percent achievement) as against the target of 23,363 class-rooms; repairing works of 9431 schools (80.5 percent achievement) were completed as against the target of 11,712 schools; 6,242 tube-wells (55.8 percent achievement) were setup as against the target of 11,191 (one tube-well for each school); 3,28,00 pairs of benches (74.4 percent achievement) were supplied as against the target of 4,41,000 pairs. A total 5,745 toilets were constructed. Moreover, textbooks were supplied to the primary students free of cost in phases and by 1985 all primary students were provided with free textbooks. Despite provision of incentives to the children, enrolment ratio at the end of the Plan still remained near about its starting level. A comparative scenario between FFYP and SFYP as regards allocation of funds in different educational levels is presented below:

\section{The Third Five Year Plan 1985-90}

The Plan set a target of increasing the enrolment of primary schools to 11.6 million, which was 70 percent of the total primary school age population. Increase in enrolment during the TFYP would be mostly from retention of enrolled students. The following measures were to be considered for increasing enrolment and retention of the enrolled students:

(i) involvement of the community in management and administration of the

(ii) schools, particularly by forming parent-teacher associations at the school level;

(iii) improvement of supervision and administration of the schools by appointing Assistant Upazila Education Officers who would be responsible for inspection and supervision of 15-20 schools on an average;

(iv) management information system was to be developed and there would be provision for inbuilt and continuous evaluation of the measures;

(v) free textbooks and learning materials were to be supplied to the students which would act as a direct incentive to the students and the parents;

(vi) create physical facilities. 
In order to achieve the target of enrolment and retention of students, it was planned to reconstruct 29,563 additional class-rooms in 9,285 schools, repair and renovate 16,257 schools including 3,000 flood damaged schools, takeover 1,000 non-government schools under government management and control, appoint 4,000 additional teachers, setup 18,121 tube wells and classroom furniture $(5,56,412$ seat benches, 26,911 tables and 4,410 steel almirahs), provide free textbooks to all primary students, supply 6.15 million learning materials and 1.8 million teacher edition of textbooks, provide training and orientation of $1,95,645$ primary teachers, teacher trainers, supervisors, and educational administrators. ${ }^{26}$ The achievement was 12.0 million enrolments by 1990 (more than 100 percent) as against the target of 11.6 million. 1,000 nongovernment schools were nationalized by 1990 (100 percent achievement). These were two remarkable achievements of the government. The devastating floods of 1987 and 1988 caused serious damage to educational institutions, particularly to the rural primary schools. During 1987-90, two major rehabilitation programmed were undertaken covering about 1430 educational institutions, almost all were primary schools.

\section{The Fourth Five-year Plan 1990-95}

In the Plan steps were taken for the expansion and progress of primary education. The main drive was on the introduction of Compulsory Primary Education (CPE) free of cost for all children. In order to materialize the plan a separate Primary and Mass Education Division (PMED) was set up under the direct control of the Prime Minister for ensuring effective administration and policy support to primary and mass education. The major objectives were to ensure (i) best possible use of existing physical facilities and maintaining regional equilibrium in respect of creating new educational facilities, (ii) increase women participation at the primary level teachers, (iii) establishment of an effectual arrangement of in-service training of primary school teachers, (iv) development of primary school curricula and (v) introduction of academic supervision and administrative inspection.

The Plan made a provision of Tk.14,281.68 million for primary education and the provision was further increased to Tk.24,216.48 million through Annual Development Plans (ADPs) as against the actual expenditure of Tk.20,307.4 million (83.9 percent achievement). By the end of 1995, a total of 59,894 schools were running in the country. During the Plan period, 9398 Ebtedayee Madrashas, 394 NGO primary schools, 53 primary schools attached to PTIs, 1,566 primary schools attached to secondary schools and 1,628 Kindergarten/ primary schools were set up.

Boys enrolment in primary schools increased from 6.7 million in 1990 to 9.37 million in 1995 (increased 39.9 percent over the period), and girls enrolment increased from 5.4 million in 1990 to 7.93 million in 1995 increased 46.9 percent over the period). Thus, the increase in girls' enrolment was higher than boys' enrolment. During the Plan period Food for Education Programmed was introduced to increase the overall enrolment in the primary schools and reducing the drop out rates among the poor children.

Two Years between Fourth and Fifth Five Year Plans (1995-97)

The Annual Development Plan (ADP) 1995-96 allocated Tk.14, 024.20 million for 24 new projects and 63 spilled out of the Fourth Five Year Plan, but the amount spent was Tk.13, 029.0 million. In the ADP of 1996-97, an allocation of Tk. 15833.40 million was made for 98 projects. Primary education programmed was accorded priority over higher education.

\section{The Fifth Five Year Plan 1997-2002}

The major uncompleted programmes of the Fourth Five Year Plan(1990-95) and next two years (1995-97) relating to primary education was continued in Fifth Five Year Plan with ultimate aim of raising the literacy rate up to 75 percent by the year 2000 and 100 within 10 years. In order to achieve 70 percent literacy rate the Fifth Five Year Plan emphasized to bring all children of age group 5-11 years under formal primary educational stream within three years. Highest emphasis was given on primary education to bring all villages and mahallas under the cover of compulsory, uniform and free primary education programmed and to lunch a national movement for total literacy. Emphasis was also given to undertake continuous training of primary teachers and involvement of local government bodies in the management of primary schools. The problems of bringing all children of primary age group under the cover of primary education and to retain them for completion of fiveyear cycle as shown in the Plan are appended below:

(i) shortage of schools within accessible distance

(ii) shortage of class rooms and over crowding

(iii) lack of proper teaching aid

(iv) shortage of furniture and other supplies

(v) lack of equipment, books and supplies for students. 
(vi) Lack of professional skills of teachers

(vii) weak community involvement and lack of awareness and interest of parents

(viii) unattractive teaching/ learning environment and

(ix) Shortage of teacher

The Government administered an extensive primary education system, which involved about 80,000 primary schools, 3,24,000 teachers, and 18.4 million students. Various programmed were introduced by the government to improve the quality of primary education. To increase enrolment in primary schools and reduce drop out of students, Food for Education Programmed and stipend were introduced. Tuition was made free and text books were supplied free of cost. Simultaneously, a strong social mobilization was initiated to create awareness among the parents to send their children to schools. Establishment of schools in the private sector had also been encouraged. As a result of all these efforts of the government, enrolment of students at primary schools had increased significantly.

The table reveals that the enrolment of female students increased to 8.78 million in 1998 from 8.36 million in 1996. Male-female student ratio also increased to 51.91:48.09 in 1998 from 52.45:47.55 in 1996. Besides, $2,86,080$ children received mosque-based education during 1996-1998. Number of female teachers was increased with the introduction of government policy to recruit at least 60 percent female teachers in the primary schools. The Food for Education Programmed continued in 1243 economically and educationally backward unions of 460 upazila of the country. Programmed was undertaken to rehabilitate 17,000 primary schools damaged by 1998 flood. Under a project costing Tk. 250 million, 15,133 damaged primary schools were rehabilitated. A project for reconstruction of 262 schools-cum-flood shelters was undertaken with an allocation of Tk.250 million.

\section{Conclusion}

It is evident from the above discussion and analysis relating to the reforms in legal and administrative structures of the country that since 1882 a lot of changes have been made for implementing compulsory primary education free of cost and of same standard for all the children of the country. As such the legal and administrative structures of the country have been going through a continuous change over the period, but actual achievement in fulfilling the target is not so encouraging and worthy to be mentioned. In practice on policy change or administrative change will bring any result without the sincere and pragmatic efforts of all concerned. The achievement of all the Five-Year and Two-Year plans was also very low and dissatisfactory. In some cases the achievements were even below fifty percent of the targets. It is very difficult to find logical relation between target and achievement in all the Plans that have been reviewed in this chapter. Our Plans are ambitious but achievements are poor. It has not yet been possible to set any appropriate target date by which free and compulsory primary education will be extended to all children in the age group of 6-11 years. The general public and the academicians of the country are anxious about the past failure of the Government in implementing the directives of Article 17 of the Constitution. They want that all the future Plans should be achievable and the targets should be realistic. The public demand, therefore, is a revised realistic program for providing universal primary education to all children and it should be implemented in a sustained manner. In fact nothing will succeed until and unless a pragmatic approach of the Government to the whole issue and their political will and commitment for implementing universal primary education for all children of the country.

\section{References}

[1]. Karim, M. "Primary Education in East Pakistan", Education for All, Papers and Proceedings of the Symposia, East Pakistan Education Week 1966-67, Edited by Abdullah Al-Muti Sharafuddin (Dacca: 5 March, 1967), p. 50.

[2]. Sattar, Ellen. Universal Primary Education in Bangladesh, Dhaka: University Press Limited, 1982, p. 16.

[3]. GOB, The Primary Schools (Taking Over) Act (The Bangladesh Gazette Extra, Feb. 5) 1974.

[4]. GOB, The Primary Education Act, 1981 (Act No IV of 1981) (Bangladesh Gezatte, Extra, dated the 30 ${ }^{\text {th }}$ April, 1981 ), p.2.

[5]. GOB, The primary Education Act, 1981 (Act no IV of 1981) (Bangladesh Gazette, Extra, dated the 30 ${ }^{\text {th }}$ April, 1981), pp. 5-6.

[6]. GOB, Decentralization of Powers and Functions Relating to Management of Primary Education (No. SX/1OM-5/82/735-Edn. (Dhaka: Ministry of Education, the $15^{\text {th }}$ August, 1983), p. 3.

[7]. GOB, Decentralization of Powers and Functions Relating to Management of Primary Education (No. SX/1 OM-5/82/73 5 -Edn. (Dhaka: Ministry of Education, the $15^{1}$ August 1983), p. 4.

[8]. GOB, The Primary Education ('Compulsory) Act, 1990 (Bangladesh Gazette Extra, 13 ${ }^{\text {th }}$ February, 1990.

[9]. Kabeer, Naila; Geetha B. Nambissan, Ramya Subrahmanian (eds.), Child Labour and the Right to Education in South Asia: Needs Versus Rights? (New Delhi: Sage Publications, 2003), p. 292.

[10]. GOB, National Education Policy 2000 (English Version), Dhaka: Ministry of Education, p. 5.

[11]. Education in Orissa under the British Rule. (1803-1936), p.1.

[12]. Prof. Zainul Abedin Chowdhury and Md. Arizul Islam Khan, The Education Policy of Bangladesh: Historical Analysis, MAEM Journal, National Academy for Educational Management (NAEM) Ministry of Education, Dhanamondi, Dhaka-120. Volume-2, Issue-4, January-June2007, p. 129. 
[13]. J P Naik, Elementary Education in India, New Delhi: Allied Publishers Private Limited, First Edition, 1975, p. 7.

[14]. Ibid.,p. 7.

[15]. A. H. M. Karim, op. cit., p. 52

[16]. F. E. Keay, and D.D. Karve, A History of Education in India and Pakistan, London: Oxford University Press, 1964, p. 209.

[17]. J P Naik, op. cit., p. 7-8.

[18]. Central Advisory Board of Education: Report on Post-War Education Development, United Press of India, 1944, p.12.

[19]. H. M. Karim, op, cit., pp. 53-54.

[20]. Proceedings of the Pakistan Education Conference, Resolution no. 16(i) $, 1947, \mathrm{p}$.

[21]. A. H. M. Karim, op. cit., p. 52

[22]. F. E. Keay, and D.D. Karve, A History of Education in India and Pakistan, London: Oxford University Press, 1964, p. 209.

[23]. J P Naik, op. cit., p. 7-8

[24]. Central Advisory Board of Education: Report on Post-War Education Development, United Press of India, 1944, p.12.

[25]. H. M. Karim, op, cit., pp. 53-54.

[26]. Proceedings of the Pakistan Education Conference, Resolution no. 16(i),1947, p. 